\title{
Entomotherapy: a study of medicinal insects of three ethnic groups in Semkhor Area, Dima Hasao District, Assam.
}

\author{
Sri Ron Kemprai, Dr. Ajit Kr. Tamuli, Dr. Robindra Teron
}

\begin{abstract}
Introduction: The ethnic communities in Semkhor have kept a close relationship with nature since time immemorial and have traditionally used different kinds of insects and their products as folk medicine to treat a variety of human ills and diseases. The present study was conducted to record the entomotherapeutic practices of seven different ethnic groups of Semkhor.

Method: Documentation is based on semi-structured questionnaires and group discussions with a total of 170 informants. The data collected were analysed using fidelity level (FL) and informant consensus factor (ICF).

Results: Fifty species of medicinal insects belonging to 21 families and 09 orders were identified in connection with treatments of at least 53 human ailments, of which the most frequently cited were coughs, gastritis, rheumatoid arthritis, stomach ache and wound healing. Mylabris sp. showed the highest fidelity level (FL) of $100 \%$ for its therapeutic property as a dermatologic agent, while the informant consensus factor (ICF) ranged from 0.66 to 1.00 . The use of medicinal insects varies amongst the seven ethnic groups, suggesting that differences in cultures and geographic location can lead to the selection of specific insect species for specific medicinal purposes. The largest number of insect species appears to be used for treating gastrointestinal, dermatological and respiratory diseases.

Conclusion: The list of medicinal insect species, many of which are reported for the first time in the present study, suggests the presence of a considerable diversity of therapeutically important insect species in the region and elaborate folk medicinal knowledge of the local ethnic groups. This knowledge of insects not just as a food, butalso as therapy is passed down verbally from generation to generation, but is in danger of being lost if not documented in a systematic way. Having stood the test of time, traditional folk medicinal knowledge and its contribution through entomotherapy should not be regarded as useless as it has the potential to lead to the development of novel drugs and treatment methods.
\end{abstract}

Keywords: Entomotherapy, Fidelity level, Informant consensus factor, Medicinal insects, Traditional knowledge. 


\section{Introduction}

Humans share the planet with a bewildering variety of animals and plants, forming an intricate web of interactions. Although plants and plant derived materials make up the majority of the ingredients used in most traditional medical systems worldwide, whole animals (vertebrates as well as invertebrates), animal parts and animal derived products also constitute important elements of the material medica. The traditional medical knowledge as a part of local cultures has played an important role in identifying biological resources worthy of scientific and commercial exploitation. Eggs, larvae, pupae and adults of certain insect species have been components of the human diet for thousands of years, be it as a regular food item or sustenance during famines, as an ingredient of medicines or part of ritual practices and even novelties.

The intertwining of the origin of the medicinal use of insects with their use as food is apparent from recorded history, but the use of insects purely as food to promote health cannot always be clearly separated from the insects' and their products' role solely to fight disease. It has been suggested that by the time insects were prescribed for therapeutic purposes by traditional healers and practitioners in South America, people were more familiar with the idea of eating them. However, in Europe, it seems to have been the opposite with medicinal uses predating culinary uses. With the development of modern drugs, folk medicinal practices involving insects gradually became sidelined and dismissed, often seen as superstition or outright nonsense, because of weird and uncommon instructions how to carry out the procedures that supposedly would heal body and soul. However, some of the recommended remedies have stood the test of time and done well with some scientific validation. Yet, overall medically important terrestrial arthropods have not yet benefitted much from the upswing in activity or the current interest in food insects and have received far less attention than the latter.

Figures provided by Meyer-Rochow, in which Google searches for 'entomophagy' and 'insects as human food' yielded 140,000 and 10,300 hits but searches with 'entomotherapy' and 'medicinal insects' only resulted in 11,100 and 7110 respective hits, underscore this fact.

It has been reported that worldwide at least 1000 species of insects are used therapeutically and given the dearth of knowledge in this field the real figure may be considerably higher. Approximately 300 medicinal insect species distributed in 70 genera, 63 families and 14 orders are reported from China alone and hundreds more of insects to treat diseases of humans as well as domestic animals have been reported from many other parts of the world, to name but a few: Tibet, Japan, Korea, India, Spain, Turkey, Africa, South America and numerous more summarized in. However, there is not works in the field of ethnozoology and entomophagy, a detailed study 
focusing on entomotherapy is lacking for Assam, Dima Hasao, Semkhor.

As part of the Tri-Junction of three States (Assam, Nagaland and Manipur), Semkhor is situated in the foothills of Borail Ranges with the ethnic communities of the region that have kept a close relationship with nature since time immemorial. Semsa's like hundreds of other ethnic communities of the world are known to use different kinds of plant and animal food products as remedies to treat their sick. However, given the dissimilarities in culture, customs and habits amongst the various tribes and the geographic and climatic characteristics of the distinctive regions, differences are to be expected in regard to the appreciation of insects as food/medicine and the way specimens are gathered and processed by the tribals. Although spiders, centipedes and myriapods are arthropods like insects and together with other invertebrates like snails and earthworms are widely used therapeutically, the present work focuses solely on insects, because it would have been beyond the scope of this investigation to also consider invertebrates other than insects. The aim of this research has been to record the folk traditional knowledge, regarding medicinal insects, present in seven different ethnic groups of Semkhor that the first author of this paper had an opportunity to interview and work with. To what extentother invertebrate species are used therapeutically and how Semsa tribes other than those covered in this publication use invertebrates to treat illnesses as well as physical and mental disorders must remain subjects of future investigations.

\section{Materials and methods}

\section{Study area}

Study area and the people: Semkhor or the Semsa territory lies between $25.26^{\circ} \mathrm{N}$ latitude and $93.30^{\circ} \mathrm{E}$ longitudes and covering a geographical area of 370 hector and comes under Maibang subdivision of Dima Hasao district (Fig.1). Semkhor is about 35 KM from Maibang. Semsa are distributed in six villages within their territory with a total population of 837 as per 2011 census.

Agriculture is the main economy of the Semkhor, which includes not only crop growing but all other allied activities such as semi-wild animal rearing,(Buffalo) i.e. poultry, horticulture, pisciculture, sericulture, silviculture, livestock, e.g Two types of farming systems-jhum or shifting cultivation and wet or terrace cultivation are practiced by the ethnic groups. Jhum cultivation is an extensive method of farming in which the farmers rotate land rather than crops to sustain livelihood. Areas of jhum land are cleared once in ten to twelve

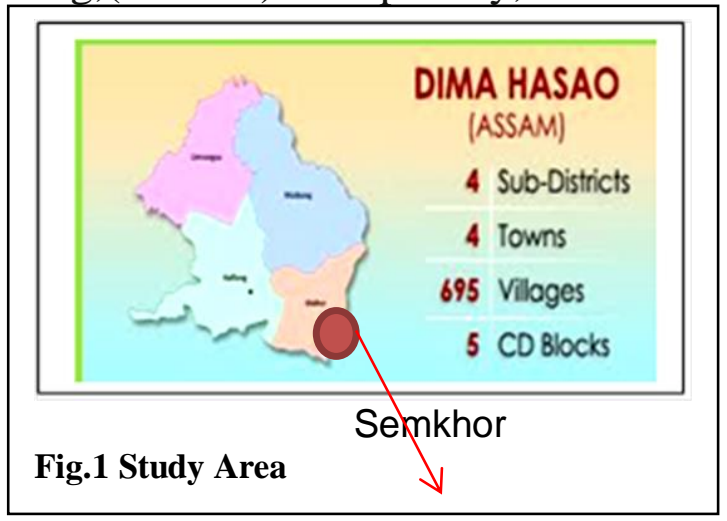


years for better crop production during which farmers

come into contact with a wide variety of insects. In terrace cultivation, the entire hillside is cut into terraces, irrigated by a network of water channels that flow down from one terrace to the other and easier to maintain than the jhum plots. However, due to the area's wide altitudinal variation, terrace cultivation is found only in some rural pockets and the majority of the population is engaged in shifting cultivation. Rice (Oryza sativa L.) is the dominant crop and the main staple food of the Semsa's, although certain cereals like maize (Zea mays L.), millet (Eleusine coracana (Gaertn.), Setaria italica (L.) P. Beauv., Pennisetum typhoides (Burm.) and Job's tears (Coix lacryma-jobi L.) are also cultivated.

The present study is based on a 2-year field survey from 2019 to 2021 involving 18 villages (Fig. 2) across Semkhor are viz. Semkhorma, Makalu, Medikal, Jalua, Doirangi, in Semkhor. The target groups for the study were the Semsa, Dimasa, Zeme, tribes, having respective representations of $13.3 \%, 14.0 \%$, and $13.9 \%$ of the total tribal population of Semkhor. Members of the mentioned tribes differ from each other not Just physically but speak different dialects and follow differrent customs and habits. Demographic patterns of informants, design of semi-structured questionnaire, etc. Usedin the present study are available from http://www.mdpi. com/2304-8158/9/7/852/s1

Percentage of Participation.

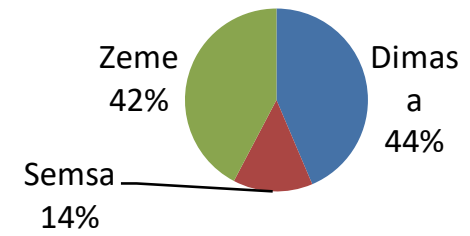

Fig. 2 Percentage of representative of Ethnic group

Informants, who were all nominally Hindus, were selected purposively on the recommendation of the community head, who was deemed the most knowledgeable and influential person. The survey was conducted only after getting ethical approval from Villages Headman, the village elders as well as the informants themselves. Therefore, with the help of semi-structured questionnaires, personal interviews with 170 informants (118 male and 52 female), most of them illiterate and ranging in ages from 24 to 94, were conducted with village heads, edible insect farmers, edible insect collectors, elderly people, educated youths, homemakers and traditional healers. The informants were asked about the whole insect or parts used for treating various ailments emphasizing the mode of preparation. The question on the strength of the family refers to the number of family members and data on income were only sought from insect vendors and may be used in a different publication. Folk stories, songs, proverbs and idioms containing references to insects abound, but will be the subjects of some publication in the future. Photographs and voucher specimens of species referred to in this paper were deposited at the Department of Zoology, Haflong Govt. College, Haflong.

\section{Data analysis}


Two quantitative tools (fidelity level and informant consensus factor) were used for data analysis. To evaluate the effectiveness and importance of a species for a particular disease, the fidelity level (FL) was used: FL $(\%)=\mathrm{Np} / \mathrm{N} \times 100$ (where, $\mathrm{Np}$ is the number of informants that claimed the use of an insect species to treat a particular disease and $N$ is the number of informants that used the insects as a medicine for any given disease). To identify an insect species with high fidelity level, simple use mentions (UM), which refer to the mentions for one insect given by all the informants for a specific disease is cited.

To analyse the general use of insects, the informant consensus factor (ICF) was used. In order to use this tool, illness was classified into broad disease categories such as problems deemed (1)Endocrinology, (2) dermatological, (3) respiratory, (4) gynaecological /andrological, (5) pain, (6) fever (including malaria), (7) urological, (8) skeleton-muscular, (9) ophthalmological, (10) to represent diabetes, (11) cardiovascular, (12) due to venomous animal bites, (13) gastrointestinal (14) oncologic, (15) to have cultural filiations, and (16) to be due to other characteristics. The ICF was calculated according to as the number of use citations in each category (Nur) minus the number of species used (Ns).

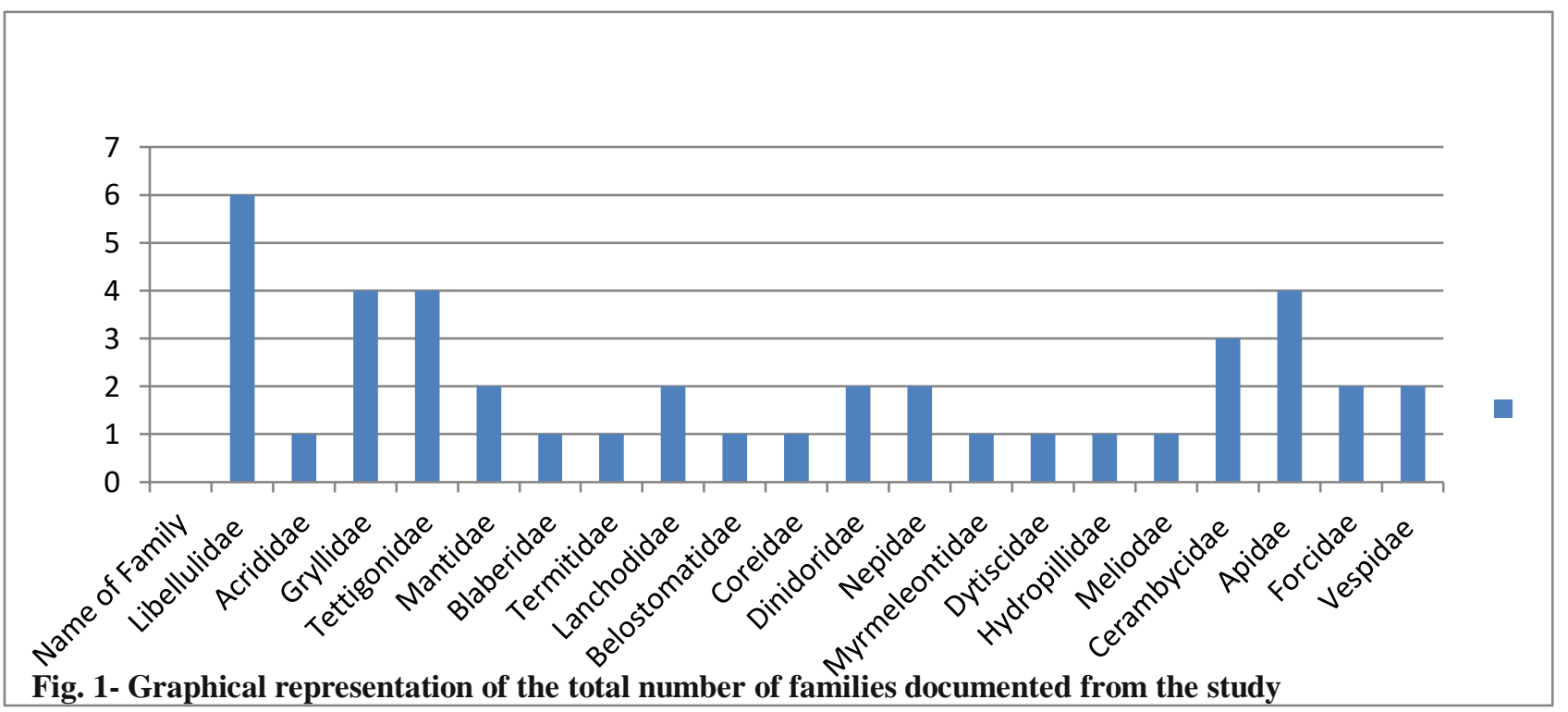

\section{Results}

\section{Diversity of medicinal insects}

The present study recorded 41 insect species belonging to 21 families and 09 orders for treating at least fifty different kinds of human ailments of which the most frequently cited ones amongst the ethnic groups were coughs, gastritis, rheumatoid arthritis, stomach ache and wound healing. Details regarding the medicinally usedinsect species are given in Table 1. The latter includesthe insects' local vernacular names, their habitats, the parts used as well as reasons for their uses. In 
addition to the disease category that the therapeutic insects are used for, tribal preferences/utilization are also mentioned and any specific therapeutic knowledge is emphasized.

The dominant families reported in the study are theLibellulidae (16\%), followed by Apidae (12\%), Cerambycidae (8\%) and Vespidae (6\%) (Fig. 2). Orders represented in the study are Odonata (6 spp.; 16\%), Orthoptera (9 spp.; 10\%), Mantodea (2 spp.; 4\%), Phasmatodea (2 sp.; 2\%), Blattodea (2spp.; 4\%), Hemiptera (8 spp.; 14\%), Neuroptera (1 sp.; 2\%), Coleoptera 6 spp.16\%),

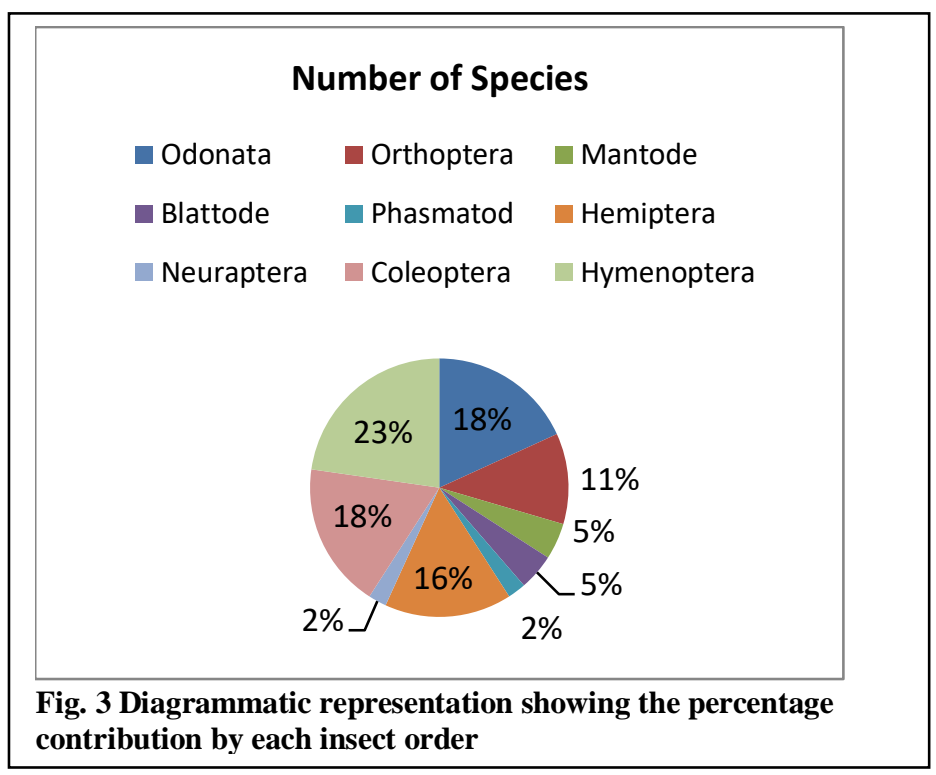
Hymenoptera (7 spp.; 20\%), (Fig. 2). It would, of course, have been desirable for the analysis to possess data on the total number of insect species known to the interviewees, but the region the survey was carried out is considered one of theremotest in India and according to the Zoological Survey of India a large number of insects of that part of India remains unrecognized and undescribed. Besides, the 'species concept' of the local people is very different from that used by scientific taxonomists.

Important medicinal insect species are used in their larval, nymphal, pupal and adult stages or as by-products. Freshly harvested insects are preferred in traditional medicines and 100\% of the informants have utilized at least one medicinal insect or its derived products in their life. Certain important medicinal insects reported are presented in Fig. 4. Of the 41 medicinal insects, 38 species were also highly appreciated as food while 3 insect species (Carausius sp., Myrmeleon sp. and Mylabris sp.) were considered inedible and only meant to be used for topical application and to treat certain ailments like blisters, calluses and warts. Medicinal insects for treating human ailments are mostly used as a dilution $(n=53 ; 20 \%)$, boiled $(n=36 ; 13 \%)$, in a soup $(n=36 ; 13 \%)$, as a decoction $(n=32 ; 12 \%)$, as paste/poultice $(n=24 ; 9 \%)$ or in cooked form $(n=20 ; 7 \%)$. 


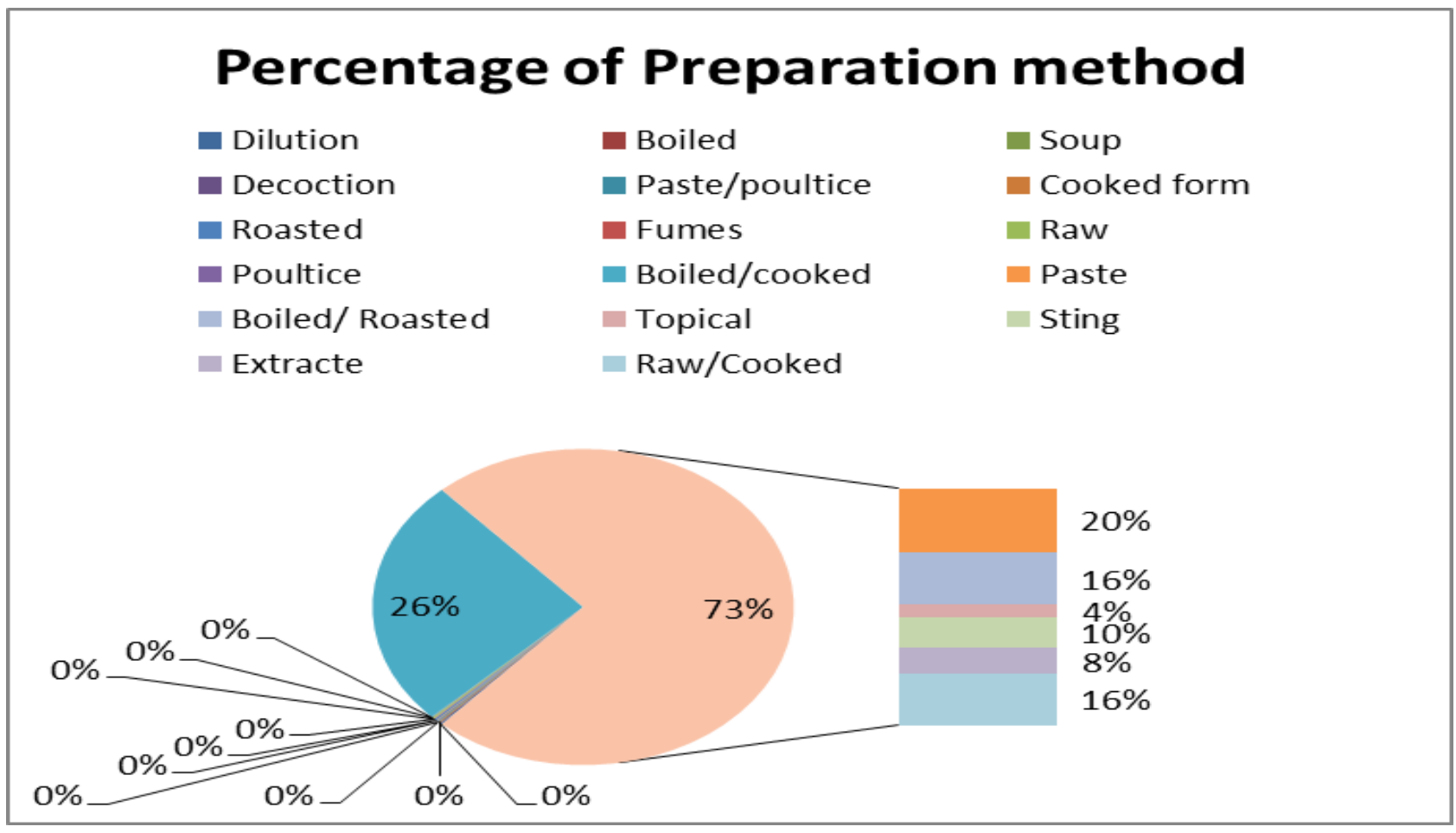

Fig.4 Percentage contribution of different preparation methods of medicinal insects.

The percentage-wise contribution of the different preparation methods is presented in Fig. 5. Medicinal insect species that are reported in the present study are mostly collected from the wild terrestrial $(n=19 ; 39 \%)$ and wild aquatic environments $(n=15 ; 28 \%)$. Trees $(n=8 ; 15 \%)$, underground burrows $(n=3 ; 7 \%)$, paddy fields $(n=2 ; 5 \%)$ and one sp-ecies each obtained from home garden, both homegarden and wild,and sandy habitats were also mentioned (Fig. 6).

The insects with major numbers of use indications for any disease were Vespa mandarinia (153), Apis cerana indica (98), Lepidotrigona arcifera (82), Lophotrigona canifrons (83),

Samia cynthia ricini (75.4), Macrotermes sp.(52), Elimaea securigera (19), Apis dorsata dorsata (15), Apis laboriosa (15) and Apis florea (14). Insect species with the most citation uses in Semsa folk medicine were the common Indian honey bee

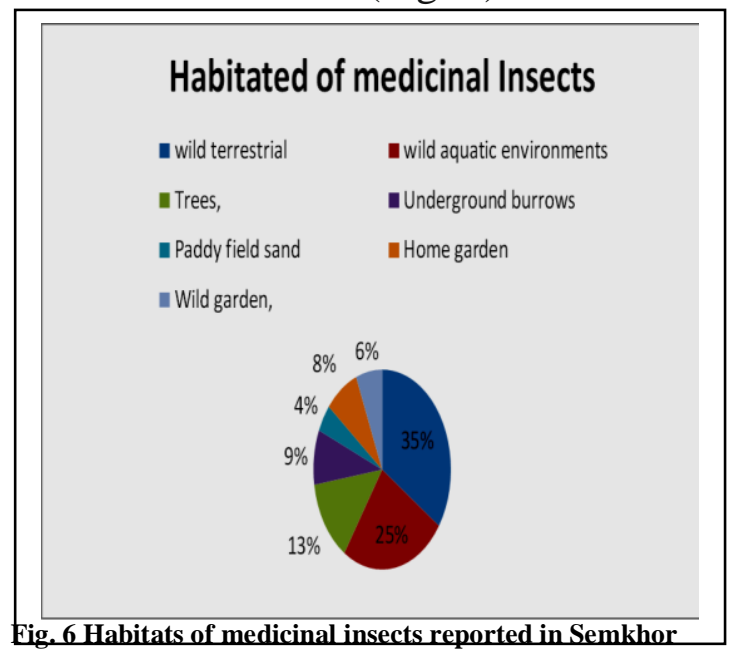

Apiscerana indica and the stingless bees Lepidotrigona arcifera and Lophotrigona canifrons.

\section{Fidelity level}

In terms of fidelity level value (Table. 1) 
, Melanoplus sp.

$(\mathrm{FL}=51 \%)$ turns out the most important species for the gastrointestinal category particularly preferred by the Lothatribe. The value indicates that indigestion is the most common ailment treated. Mylabris sp. $(\mathrm{FL}=100 \%)$ is the most important species for the dermatological category with warts as an ailment receiving the majority of treatment amongst the Semsa tribe besides Dimasa and Zeme tribes. All seven ethnic groups consider Apis laboriosa and Apis florea ( $\mathrm{FL}=82.7 \%$ ) to be the most important species in treating the respiratory problems with coughs being the most common ailment to be treated, while the stingless bees Lepidotrigona arcifera and Lophotrigona canifrons $(\mathrm{FL}=16.5 \%)$ are regarded as the most important species among the Dimasa and Zeme tribes for gynaecological/andrological problems with easy labour as a significant use category. Udonga montana $(\mathrm{FL}=87.5 \%)$ and Coridius singhalanus $(\mathrm{FL}=41.8 \%)$ were most important in connection with pain and fever, respectively, with analgesic and jaundice being the dominant ailments to be treated. Dragonfly nymphs ( $\mathrm{FL}=60.9 \%$ ) were the leading insects in the skeleton-muscular problem category characterized by body aches as well as for ophthalmological problems like conjunctivitis (FL $=$ $51.5 \%)$.

The praying mantis Hierodula coarctata $(\mathrm{FL}=42.1 \%)$ was the choice species in the urological category with enuresis as the significant ailment whereas, the stingless bees Lepidotrigona arcifera and Lophotrigona canifrons $(\mathrm{FL}=19.5 \%)$ were the most important species in connection with venomous animal bites, in which snake bites featured as the main and most serious problem. The giant water scorpion Laccotrephes ruber ( $\mathrm{FL}=21.4 \%$ ) was the most important species in the cardiovascular category given its assumed blood purifier properties, while in the diabetes category Melanoplus sp. ( $\mathrm{FL}=46.9 \%$ ) came out as an important species utilized, only, however, by the Zeme tribe. In the oncologic and cultural filiation's category, the stingless bees Lepidotrigona arcifera and Lophotrigona canifrons ( $\mathrm{FL}=3.2 \%$; FL $=$ 2.7\%) once again reached the number one position of the important species and it was emphasized by the informants that the honey of stingless bees kept for 7 years or more (possibly undergoing some fermentation) was particularly medicinal. 


\section{Informant consensus factor}

It is evident from the informant consensus factor (ICF) that there are some parallel usages of medicinal insects among the seven ethnic groups. The parallel use of insect species may be due to coincidence, similar criteria for selecting insects or shared information on the potential usefulness of a species. The similarities and differences with regard to the utilization of certain kinds of medicinal insects reported in the present study suggest that cultures differing in traditions and languages interact with each other, but also develop their own preferences. Of the fifty medicinal insects, the maximum number of species is used for gastrointestinal, respiratory and dermatological problems (Table 2). In comparison with Dimasa, Semsa, and zeme tribes, the zeme tribe showed the highest ICF values. A detailed summary of the ICFs for the seven ethnic groups is presented in Table 3. The ICF values for the Dimas tribe indicate that fever, diabetes, oncologic and the disorders of the urological category scored the highest $(\mathrm{ICF}=1.00$ ) while the ophthalmological category $(\mathrm{ICF}=0.84)$ scored the lowest consensus value when compared with other sickness categories. It is also evident that dermatological and respiratory problems $(\mathrm{ICF}=0.95$ ) had the highest ICF values among the Semsa tribe while the pain category $(\mathrm{ICF}=0.73$ ) received a lower consensus. Categories like diabetes and venomous animal bites recorded the highest value $(\mathrm{ICF}=1.00)$ amongst the Zeme tribe, while the dermatological category ( ICF $=0.84$ ) showed a lower consensus compared with the other sickness categories. However, for the Dimasa tribe, the dermatological category recorded the highest value $(\mathrm{ICF}=0.95)$. The pain $(\mathrm{ICF}=1.00)$ and gynaecological categories $(\mathrm{ICF}=1.00)$ recorded the highest values among the Semsa and Dimasa tribes, respectively, whereas skeleton muscular problems, with an ICF of 0.97, yielded the highest value amongst the Semsa tribe.

Diversity of medicinal insects among the ethnic groups- The present study reported a total of 50 medicinal insects. However, not all of the insect species were utilized by all seven ethnic groups. Of the seven ethnic groups, the Semsa and Dimasa tribes use the maximum number of insects for therapy with 31 species followed by members of the Sensa tribe with 24 species; the least number of insect species used therapeutically is 11 by the Zeme tribe (Fig. 7).The order-wise distribution of medicinal insects among the seven ethnic groups is presented in Fig. 8. A given insect species may be used for different purposes by different ethnic groups. For instance, dragonfly nymphs are reported to be used by only two tribes (Dimasa and Zeme). But while the Semsa tribals use dragonfly nymphs for treating body aches, cold and ophthalmological problems, zeme use dragonfly nymphs for healing wounds.

The field cricket Tarbinskiellus portentosus, utilized by the Semsa and zeme tribes, serve different medicinal purposes for these two tribes. While the semsa use the cricket to treat malaria, the Dimasa tribe uses it in connection with headaches and gastrointestinal problems. Dimasa and Semsa tribes have identical medicinal uses for the mantis Tenodera sinensis, namely for treating warts. Similarities among the 
Semsa and zeme tribes with regard to Lethocerus indicus have been reported whereby the bugs are used to treat gastrointestinal problems. Besides gastro-intestinal problems, the Dimasa tribe also uses giant water bugs as a remedy for rheumatoid arthritis and wound healing. The dinidorid bug Coridius singhalanus is used by the Semsa, Dimasa and zeme tribes. However, while the zeme and Sumi share the same traditional therapeutic knowledge (treating jaundice), the Semsa tribe uses the bugs for treating malaria and to increase milk production in lactating mothers. Dimasa and Semsa tribes share the therapeutic knowledge of Laccotrephes ruber being an important medicinal agent to treat gastrointestinal problems. However, in addition, water scorpions are also used as a remedy for treating rheumatoid arthritis by the Semsa tribe.

All of the seven tribes share the therapeutic knowledge that involves the larvae of wood borers (Batocera rubus, Batocera parryi, Batocera rufomaculata and Orthosoma brunneum) as an analgesic and a remedy to treat gastrointestinal problems. However, the Semsa tribe also uses them for treating malaria and typhoid whereas the Zeme tribe takes them as an aphrodisiac. The larvae of the banana skipper Erionata torus are used as an aphrodisiac by the zeme tribe, but the semsa tribe use them to reduce the effects of venomous animal bites. While the Semsa and Dimasa tribes share similar therapeutic knowledge with regard to crane flies of the genus Tipula as an analgesic, the Semsa use the larvae for treating measles in children.

\section{Discussion}

Healing with insects: traditions of the Semsa and other Indian tribals

The list of medicinal insect species in the present study highlights the diversified insect use as traditional folk medicine among the tribal communities of Semkhor. There are similarities with other ethnic tribes in the world, generally, and different regions of the country, in particular, as bees (Hymenoptera) and their products, but furthermore beetles (Coleoptera) and bugs (Hemiptera), dominate the list of the therapeutic species. The relatively high importance of dragonflies (especially as nymphs), but also aquatic beetles, an aquatic cockroach and species of the Neuroptera, however, makes the Semsa therapeutic use of insects stand out Insect and insect derived products provide ingredients that have been a staple in traditional medicine for centuries in many parts of the world and although many of these ingredients still have not been evaluated experimentally, an increasing number of them have been identified and shown to have beneficial properties. Because of its antimicrobial, anti-bacterial, anti-cancer, anti-diabetic, antihypercholesterolemia, anti-inflammatory, antioxidant and wound healing properties, Semsa consider honey to be an extremely important medicinal agent for treating a multitude of human ailments such as cancer, cholera, gastrointestinal problems, respiratory problems, ophthalmological problems, etc. Six different types of honey are used by the Semsa tribes in wound healing and for treatment of other disorders such as 
infections and irritable bowel syndrome which is also reported elsewhere.

The present findings of an ophthalmological use and topical application of honey over deep wounds as well as the use of bee pupae and bee hive material to treat back pain, throat pain and menstrual disorders is in accordance with the tribal communities of Madiya Pradesh in India and people elsewhere in the world. The oral administration of honey and bee comb/wax of the species Apiscerana indica, Apisdorsata and Apis florea, practiced by mostly tribal people in treating asthma, cancer, coughs, colds, diarrhoea, gastritis, mouth ulcer, skin diseases, stomach pains, symptoms of nausea and various respiratory diseases as well as labour pains, shows similarities to that of indigenous people from other parts of India and indeed the world.

The therapeutic practice to use adult ants (Oecophylla smaragdina) among various tribes in Semkhor for the treatment of coughs, fever, malaria, typhoid, oedema, sinus infections and as an analgesic has also been reported from Assam, Arunachal Pradesh, Tamil Nadu and Kerala. These common uses are almost certainly due to the observation that pharmacologically active compounds with antioxidant, anti-arthritic and antimicrobial activities in the abdominal glands of the species provide relieve of debilitating symptoms. There would, of course, also have been cases in which members of different tribes exchanged their therapeutic knowledge. An identical use of boiled dragonfly nymphs for wound healing has also, for example, been reported from the Meitei community of Manipur, a state of North-East India with a significant proportion of Tribal inhabitants.

\section{Comparisons with other tribes and countries}

The use of Melanoplus sp. to treat certain intestinal disorders and stink bugs as an analgesic and for remedying stomach aches and rheumatoid arthritis shows similarities with ethnic Mexican communities and, therefore, represents a convergent and independently discovered therapeutic use of an insect. The oral administration of the timber borer (Orthosoma sp.) as an aphrodisiac by Semsa bears similarities to the practice of rural people in Mexico but must have been discovered independently. The reported use of Carausius sp. to treat prickling spines and skin related diseases as well as the topical application of Myrmeleon spp. to treat warts are shared with the traditional therapeutic practices of the ethnic communities of the North-East Indian state of Mizoram, which suggests contacts between Nagaland and Mizoram inhabitants. The topical application of Mylabris sp. for treating blisters and warts reported in our study also features in the traditional Chinese and Korean medical pharmacopeia and is almost certainly based on the widely known presence and function of cantharidin derived from the bodies of blister beetles. However, certain differences between the therapeutic uses of insects in Semkhor with those of other countries cannot be ignored. For instance, stick insects are used for treating calluses, warts and prickling spines by the Semsa tribes, but in North Korea they are considered to contain potent healing powers and 
used to cleanse the body as well as to remove stomach upsets. While, Gryllus spp., Aspongopus nepalensis and Oecophylla smaragdina are used for treating dysentery, jaundice and as an analgesic to treat coughs, malaria, typhoid, oedema, fevers and headaches by the Dimasa, their uses in the treatment of pneumonia, malaria and digestive problems, respectively, have been reported from the North East Indian states of Tripura, Mizoram and Arunachal Pradesh.

The blister beetle Mylabris sp. is used by semsa to treat blisters and warts, but the same species has been used to treat tumours or cancers in China. Silkworms are used as an analgesic, nutrient supplement and for blood sugar control by the Nagas, while in Japan; they are used to cure a sore throat and nephritis. Furthermore, Hierodula coarcta, Tarbinskiellus portentosus, Gryllus spp., Cybister sp., Mylabris sp., Batocera spp. and Apis cerana indica are used to treat dermatological problems, headaches, malaria and gastrointestinal problems by the various semsa tribes, but in China the aforementioned insect species are used to treat impotence, relieve body swellings, fever, foster detoxification, improve blood circulation, assist in managing rheumatism, menstrual symptoms and arthritic pains.

\section{For each malady one species or one species for all ills?}

Based on these inconsistent findings, the questions one can ask are: how is it possible that one and the same species can be good for a multitude of illnesses and how can it be that there are treatments for identical disorders involving a variety of often taxonomically not even closely related species? Meyer-Rochow has tried to answer these questions by pointing out that in the small bodies of insects a great variety of distinct compounds like metabolites, enzymes, hormones, neurotransmitters, etc. exist and that the different preparation and administration methods used by traditional healers could lead to an activation of different molecules in the therapeutic species, affecting different organs and exerting specific effects in the treated person. Since the chemical composition of insects stems either directly or in case of metabolites indirectly from the food that they have ingested during their growth phases, there is also the possibility that identical species, but occurring in different habitats and regions with differing soil and microclimatic conditions, obtained non identical ingredients, which could then result in non-identical effects with regard to the potency of these insects' various bioactive compounds.

The second question, namely that taxonomically unrelated species can be used to treat disorders or diseases in humans is likely to be related to the fact that insects can suffer from pathogenic agents like viruses, bacteria, fungi, etc. that also occur in vertebrates and that in the cases of cancers, which invertebrates can also suffer from, proliferating cell lines as in human cancers, are inevitably involved. Insects have had hundreds of millions of years to evolve efficient defenses against these common pathogens and it would have been 'far more surprising to find that each group or even each species had evolved its own unique defense system fighting disease'. Thus, the explanations of how the therapies with dissimilar insect species 
can lead to identical outcomes and why on the other hand sometimes one and the same species can be used in connection with different disorders can be summarized in the following way: the treatment results very likely depend firstly on the food and habitat characteristics that the therapeutic species used in the treatment had experienced earlier in their growth phases; secondly, on the pre-treatment that the remedy had undergone before administration; and thirdly, on the details of how the remedy is to be administered to the suffering person. Thus, to record and identify not only the various therapeutic species but also from which region and habitat they came from as well as the particular ways in which they are meant to be used therapeutically is important. Sadly, this information is frequently missing and due to the secrecy that traditional healers often attach to their methods, the latter are ever so often not exactly easy to come by or even appreciated by those who manage to obtain them. Folk traditional knowledge, also referred to as 'common sense', and its contribution through entomotherapy should therefore not prematurely be regarded as useless and outdated but has to be scientifically scrutinized. There is real potential that such studies can lead to the development of novel drugs and alternative treatment methods.

\section{Conclusion}

Besides their use as a food item among the various ethnic groups in Semkhor, insects are also widely used therapeutically. Our documentation of at least 41 medicinal insects from seven tribes in Semkhor suggests that folk traditional knowledge is still a part of the tribal lives in the state. The list of medicinal insect species, many of which are reported for the first time in the present study, is evidence of a considerable diversity of therapeutically exploited insect species of the region and demonstrates that detailed analyses of certain bioactive substances of these species, deemed effective in treating illnesses and other disorders and given high fidelity levels by local users, could open up new prospects in the field of pharmacology.

Table. 1 insect species used by ethnic group in semkhor Area for treating various human health conditions.

\begin{tabular}{|c|c|c|c|c|c|c|c|c|c|}
\hline $\begin{array}{l}\text { Sl. } \\
\text { No }\end{array}$ & Order & Family & $\begin{array}{l}\text { Scientific } \\
\text { Name }\end{array}$ & Local Name & Habitat & $\begin{array}{l}\text { Parts } \\
\text { Used }\end{array}$ & $\begin{array}{l}\text { Diseases } \\
\text { Treatment }\end{array}$ & $\begin{array}{l}\text { Therapeutic } \\
\text { Knowledge }\end{array}$ & $\begin{array}{l}\text { FL\% } \\
\text { (category) }\end{array}$ \\
\hline 1 & Odonata & Libellulidae & $\begin{array}{l}\text { Crocothemis } \\
\text { servilia servilia } \\
\text { drury } 1773\end{array}$ & $\begin{array}{l}\text { Barsudi } \\
\text { gjao }\end{array}$ & Aquatic & Nymph & $\begin{array}{l}\text { Headache, } \\
\text { vision }\end{array}$ & $\begin{array}{l}\text { Boiled nymph } \\
\text { are eaten }\end{array}$ & $\begin{array}{l}60.9(7) ; 46 . \\
8(3) \\
39.1(8) 18.7 \\
(2)\end{array}$ \\
\hline 2 & & & $\begin{array}{l}\text { Diplocodes } \\
\text { trivialis }\end{array}$ & Barsudima & & $\begin{array}{l}\text { Whole } \\
\text { body }\end{array}$ & Joint pain & $\begin{array}{ll}\text { Raw } & \text { are } \\
\text { applied } & \\
\text { externally } & \end{array}$ & 34.6 \\
\hline 3 & & & $\begin{array}{l}\text { Neurothemis } \\
\text { fulvia Drury } \\
\mathbf{1 7 7 3}\end{array}$ & Barsudidi & & $\begin{array}{l}\text { Whole } \\
\text { body }\end{array}$ & Body ache & $\begin{array}{l}\text { Soup are used } \\
\text { for masses the } \\
\text { body. }\end{array}$ & 25.6 \\
\hline 4 & & & $\begin{array}{l}\text { Orthetrum } \\
\text { pruinosum } \\
\text { neglectum } \\
\text { (Burmeister } \\
\text { 1839) }\end{array}$ & $\begin{array}{l}\text { Barsudi } \\
\text { birgigjao }\end{array}$ & & Head & Vision & $\begin{array}{l}\text { Fumes } \\
\text { boiled } \\
\text { manually } \\
\text { applied daily } \\
\text { for week. }\end{array}$ & 51.8 \\
\hline 5 & & & $\begin{array}{l}\text { Pantata } \\
\text { flavescens } \\
\text { Fabr.1798 }\end{array}$ & $\begin{array}{l}\text { Barsudi } \\
\text { merang }\end{array}$ & & $\begin{array}{l}\text { Whole } \\
\text { body }\end{array}$ & $\begin{array}{l}\text { Conjunctivit } \\
\text { is }\end{array}$ & $\begin{array}{l}\text { Fumes of } \\
\text { boiled are } \\
\text { allowed to get } \\
\text { the eyes trice }\end{array}$ & $51.5(8)$ \\
\hline
\end{tabular}




\begin{tabular}{|c|c|c|c|c|c|c|c|c|c|}
\hline & & & & & & & & $\begin{array}{lll}\begin{array}{l}\text { daily } \\
\text { days. }\end{array} & \text { for } & 7 \\
\end{array}$ & \\
\hline 6 & & & $\begin{array}{l}\text { Patamarcha } \\
\text { congener } \\
\text { Rambur } 1842\end{array}$ & $\begin{array}{l}\text { Basudima } \\
\text { tapla }\end{array}$ & & & Arthritis & $\begin{array}{l}\text { Boiled are } \\
\text { appleid } \\
\text { externally. }\end{array}$ & 74.1 \\
\hline 7 & Orthoptera & Acrididae & $\begin{array}{l}\text { Melanoplus } \\
\text { sp }\end{array}$ & Guyoung & $\begin{array}{l}\text { Paddy } \\
\text { Maize }\end{array}$ & $\begin{array}{l}\text { Whole } \\
\text { body }\end{array}$ & Hiccups & $\begin{array}{l}\text { Roasted whole } \\
\text { body are eaten }\end{array}$ & 54.6 \\
\hline 8 & & Gryllidae & $\begin{array}{l}\text { Tarbinskiellus } \\
\text { portentosus } \\
\text { (Lichtenstein1 } \\
\text { 796) }\end{array}$ & kandrima & $\begin{array}{l}\text { Burrow } \\
\text { ing }\end{array}$ & Adult & Indigestion, & $\begin{array}{l}\text { Roasted whole } \\
\text { body are eaten }\end{array}$ & 35.2 \\
\hline 9 & & Gryllidae & Gryllus spp. & Kalampu & Burring & Adult & $\begin{array}{l}\text { Headache, } \\
\text { Loose } \\
\text { motion and } \\
\text { malaria }\end{array}$ & $\begin{array}{l}\text { Boil or roasted } \\
\text { are eaten for } \\
\text { early recovery. }\end{array}$ & $\begin{array}{l}\text { 26.3, 48.1, } \\
54.7\end{array}$ \\
\hline 10 & & & $\begin{array}{l}\text { Achta } \\
\text { domesticus } \\
\text { Linn }\end{array}$ & kandirey & Burring & Adult & $\begin{array}{l}\text { Reflux of } \\
\text { food, } \\
\text { indigestion }\end{array}$ & $\begin{array}{l}\text { Roasted whole } \\
\text { body are eaten } \\
\text { in empty } \\
\text { stomach. }\end{array}$ & 61.742 .2 \\
\hline 11 & & & $\begin{array}{l}\text { Teleogryllus } \\
\text { spp. }\end{array}$ & $\begin{array}{l}\text { Kandireygd } \\
\text { eba }\end{array}$ & Burring & Adult & $\begin{array}{l}\text { Headache } \\
\text { vomiting }\end{array}$ & $\begin{array}{l}\text { Roasted and } \\
\text { grinned } \\
\text { whole body are } \\
\text { drink with } \\
\text { water in empty } \\
\text { stomach. }\end{array}$ & $\begin{array}{l}34.9 \\
28.2\end{array}$ \\
\hline 12 & & $\begin{array}{l}\text { Tettigonida } \\
\text { e }\end{array}$ & $\begin{array}{l}\text { Pseudophyllus } \\
\text { titan, white } \\
1846\end{array}$ & Gusain & Wild & Adult & $\begin{array}{l}\text { Fever, } \\
\text { Dysentery }\end{array}$ & $\begin{array}{l}\text { Roasted whole } \\
\text { body are orally } \\
\text { administered } \\
\text { to young } \\
\text { children. }\end{array}$ & $52.1,33.5$ \\
\hline 13 & & & $\begin{array}{l}\text { Elimaea } \\
\text { securigera } \\
\text { Brunner von } \\
\text { wattenwyl } \\
1878\end{array}$ & Gudaosa & Paddy & Adult & $\begin{array}{l}\text { Nutrient } \\
\text { supplement }\end{array}$ & $\begin{array}{l}\text { Roasted whole } \\
\text { body are eaten }\end{array}$ & I72.2 \\
\hline 14 & & & $\begin{array}{l}\text { Mecopoda } \\
\text { nipponensis } \\
\text { Haan }\end{array}$ & Gubaoma & Wild & Adult & $\begin{array}{l}\text { Weight loss } \\
\text { and } \\
\text { constipation }\end{array}$ & $\begin{array}{l}\text { Boiled whole } \\
\text { body are eaten }\end{array}$ & $42.8,23.6$ \\
\hline 15 & & & Tettigonia sp & Gusainjik & Wild & Adult & $\begin{array}{l}\text { Body ache, } \\
\text { joint pain }\end{array}$ & $\begin{array}{l}\text { Roasted whole } \\
\text { body are eaten } \\
\text { and grinned } \\
\text { body and } \\
\text { externally } \\
\text { applied }\end{array}$ & $43.6,39.2$ \\
\hline
\end{tabular}




\begin{tabular}{|c|c|c|c|c|c|c|c|c|c|}
\hline 16 & Mantodae & Mantidae & $\begin{array}{l}\text { Tenodera } \\
\text { sinensis } \\
\text { Saussure } 1871\end{array}$ & Gangu & Wild & Adult & $\begin{array}{l}\text { Warts, } \\
\text { Fracture }\end{array}$ & $\begin{array}{l}\text { An whole body } \\
\text { Is allowed to } \\
\text { masticate on } \\
\text { warts. }\end{array}$ & 24.6 \\
\hline 17 & & & $\begin{array}{l}\text { Hierodula } \\
\text { coarctata } \\
\text { Saussure } 1871\end{array}$ & $\begin{array}{l}\text { Gangu } \\
\text { kasiba }\end{array}$ & Wild & Adult & $\begin{array}{l}\text { Enuresis, } \\
\text { kidney stone }\end{array}$ & $\begin{array}{l}\text { Roasted whole } \\
\text { body is orally } \\
\text { administered } \\
\text { to young } \\
\text { children and } \\
\text { drink the } \\
\text { grinned whole } \\
\text { body for } \\
\text { kidney stone. }\end{array}$ & $43.1,28.8$ \\
\hline 18 & Blattodae & Blaberidae & Epilampa sp & Pujima & Aquatic & Adult & Appetizer & Raw are eaten & 32.4 \\
\hline & & & & & & & Bloating & $\begin{array}{l}\text { Roasted body } \\
\text { is rubbed. }\end{array}$ & \\
\hline 19 & & Termitidae & $\begin{array}{l}\text { Macrotermes } \\
\text { sp. }\end{array}$ & Hurima & $\begin{array}{l}\text { Burrow } \\
\text { ing }\end{array}$ & Adult & $\begin{array}{l}\text { Nutrients } \\
\text { supplement }\end{array}$ & $\begin{array}{l}\text { Fried termites } \\
\text { are eaten. }\end{array}$ & 65.8 \\
\hline 20 & $\begin{array}{l}\text { Phasmatod } \\
\text { ae }\end{array}$ & $\begin{array}{l}\text { Lanchodida } \\
\text { e }\end{array}$ & Carausius sp & $\begin{array}{l}\text { Gangsiman } \\
\text { g }\end{array}$ & Wild & Adult & Calluses, & $\begin{array}{l}\text { Past of stick } \\
\text { insect } \\
\text { externally } \\
\text { applied for } \\
\text { quick recovery. }\end{array}$ & \\
\hline 21 & & & & & & & $\begin{array}{l}\text { Prickling } \\
\text { spines }\end{array}$ & $\begin{array}{lr}\text { Adult } & \text { stick } \\
\text { insect } & \text { is } \\
\text { rubbed } & \text { for } \\
\text { removal. } & \\
\end{array}$ & \\
\hline \multirow[t]{2}{*}{22} & Hemiptrera & $\begin{array}{l}\text { Belostomati } \\
\text { dae }\end{array}$ & $\begin{array}{l}\text { Lethocerus } \\
\text { indicus } \\
\text { (lepeletier \& } \\
\text { serville, 1825) }\end{array}$ & Kaodampi & Aquatic & Adult & Dry cough & $\begin{array}{l}\text { Soup of body is } \\
\text { orally } \\
\text { administered } \\
\text { twice a day. }\end{array}$ & \\
\hline & & & & & & & $\begin{array}{l}\text { Rheumatoid } \\
\text { arthritis }\end{array}$ & $\begin{array}{l}\text { Fumes of } \\
\text { boiled are } \\
\text { taken for quick } \\
\text { recovery. }\end{array}$ & 46.3 \\
\hline 23 & & Coreidae & $\begin{array}{l}\text { Notobitus } \\
\text { meleagris } \\
\text { Fabr.1787 }\end{array}$ & Yungsilim & Wild & Adult & $\begin{array}{l}\text { Stomach } \\
\text { ache }\end{array}$ & $\begin{array}{l}\text { Roasted are } \\
\text { eaten }\end{array}$ & 32.9 \\
\hline 24 & & Dinidoridae & $\begin{array}{l}\text { Aspongopus } \\
\text { nepalensis } \\
\text { westwood } \\
1837\end{array}$ & $\begin{array}{l}\text { yungslimga } \\
\text { mram }\end{array}$ & Wild & Adult & Jaundice & $\begin{array}{l}\text { Boiled stink } \\
\text { bugs are eaten } \\
\text { thrice a day for } \\
\text { a week. }\end{array}$ & 43.4 \\
\hline 25 & & & $\begin{array}{l}\text { Coridius } \\
\text { singalanus }\end{array}$ & Yungkidim & Aquatic & Adult & $\begin{array}{l}\text { Malaria, } \\
\text { viral fever }\end{array}$ & $\begin{array}{l}\text { Cooked stink } \\
\text { bugs are eaten }\end{array}$ & 34.5 \\
\hline
\end{tabular}




\begin{tabular}{|c|c|c|c|c|c|c|c|c|c|}
\hline & & & Dist,1900 & & & & & $\begin{array}{l}\text { daily for a two } \\
\text { week. }\end{array}$ & \\
\hline \multirow[t]{2}{*}{26} & & Nepidae & $\begin{array}{l}\text { Laccotrephes } \\
\text { ruber L.1764 }\end{array}$ & $\begin{array}{l}\text { Diniyungsili } \\
\text { m }\end{array}$ & Aquatic & Adult & $\begin{array}{l}\text { Blood } \\
\text { purifier }\end{array}$ & $\begin{array}{l}\text { Boiling nymph } \\
\text { is orally } \\
\text { administered } \\
\text { daily for a } \\
\text { week. }\end{array}$ & 31.7 \\
\hline & & & & & & & Indigestion & $\begin{array}{l}\text { Soup of boiled } \\
\text { bugs is orally } \\
\text { taken for quick } \\
\text { recovery. }\end{array}$ & 19.6 \\
\hline 27 & & $\begin{array}{l}\text { Pentatomid } \\
\text { ae }\end{array}$ & $\begin{array}{l}\text { Udonga } \\
\text { montana } \\
\text { Distant, } 1900\end{array}$ & $\begin{array}{l}\text { Yungkidim } \\
\text { merang }\end{array}$ & Wild & Adult & $\begin{array}{l}\text { Analgesic, } \\
\text { coughs }\end{array}$ & $\begin{array}{l}\text { Boiled bug are } \\
\text { eaten for quick } \\
\text { healing. }\end{array}$ & 19.5 \\
\hline 28 & Neuroptera & $\begin{array}{l}\text { Myrmeleon } \\
\text { tidae }\end{array}$ & $\begin{array}{l}\text { Myrmeleon } \\
\text { spp. }\end{array}$ & Gutulik & Wild & Larva & Diabetes & $\begin{array}{l}\text { Boiled are } \\
\text { eaten to control } \\
\text { blood sugar } \\
\text { level. }\end{array}$ & 68.8 \\
\hline 29 & Coleoptera & Dytiscidae & $\begin{array}{l}\text { Cybister } \\
\text { limbatus } \\
\text { Fabr.1775. }\end{array}$ & Khudim & Aquatic & Adult & Diarrhoea & $\begin{array}{l}\text { Boiled are } \\
\text { eaten for quick } \\
\text { recovery. }\end{array}$ & 54.5 \\
\hline 29 & & $\begin{array}{l}\text { Hydrophili } \\
\text { dae }\end{array}$ & $\begin{array}{l}\text { Hydrophillus } \\
\text { cashmirensis } \\
\text { Redtenbacher } \\
1846\end{array}$ & Gantaima & Aquatic & Adult & Boils, warts & $\begin{array}{l}\text { Cooked water } \\
\text { are eaten for } \\
\text { quick recovery. }\end{array}$ & $12.8,28.1$ \\
\hline 30 & & Meloidae & Mylabris sp & Jagai & Wild & Adult & $\begin{array}{l}\text { Gastritis, } \\
\text { head ache }\end{array}$ & $\begin{array}{l}\text { Soup of boiled } \\
\text { is orally } \\
\text { administered } \\
\text { once a daily for } \\
\text { a week. }\end{array}$ & \\
\hline 31 & & $\begin{array}{l}\text { Cerambyci } \\
\text { dae }\end{array}$ & $\begin{array}{l}\text { Batocera } \\
\text { rubus L1775 }\end{array}$ & Bondojagai & Tree & larva & $\begin{array}{l}\text { Analgaesic, } \\
\text { diarrhoea }\end{array}$ & $\begin{array}{l}\text { Decoction of } \\
\text { boiled larva } \\
\text { are orally } \\
\text { administered }\end{array}$ & 54.3 \\
\hline 32 & & & \begin{tabular}{l}
\multicolumn{2}{l}{ Batocera } \\
parry Hope \\
1845
\end{tabular} & Wajagai & $\begin{array}{l}\text { Tree/ } \\
\text { Bambo } \\
\text { o }\end{array}$ & larva & $\begin{array}{l}\text { Aphrodisiac, } \\
\text { malaria, } \\
\text { typhoid }\end{array}$ & $\begin{array}{l}\text { Soup of boiled } \\
\text { are orally } \\
\text { administered }\end{array}$ & $\begin{array}{l}\text { 45.1, 29.9, } \\
61.7\end{array}$ \\
\hline 33 & & & $\begin{array}{l}\text { Orthosoma } \\
\text { brunneum. } \\
\text { Forster } 1771\end{array}$ & Jagaigajao & Tree & larva & $\begin{array}{l}\text { Asthma, } \\
\text { coughs }\end{array}$ & $\begin{array}{l}\text { Roasted are } \\
\text { orally } \\
\text { administered. }\end{array}$ & $54.1,38.9$ \\
\hline 34 & $\begin{array}{l}\text { Hymenopte } \\
\text { ra }\end{array}$ & Apidae & $\begin{array}{l}\text { Apis cerana } \\
\text { indica. } \\
\text { Fabr.1798 }\end{array}$ & Bereyung & Wild & Honey & $\begin{array}{l}\text { Blood } \\
\text { pressure, } \\
\text { cholera, cold } \\
\text { coughs. }\end{array}$ & $\begin{array}{l}\text { One tea } \\
\text { spoonful of } \\
\text { honey is mixed } \\
\text { in warm water }\end{array}$ & $\begin{array}{ll}45.1, & 67.2 \\
67.8 & \end{array}$ \\
\hline
\end{tabular}




\begin{tabular}{|c|c|c|c|c|c|c|c|c|}
\hline & & & & & & & $\begin{array}{l}\text { and oral } \\
\text { administered } \\
\text { for quick } \\
\text { recovery. }\end{array}$ & \\
\hline & & & & & Honey & $\begin{array}{l}\text { Asthma } \\
\text { sinusitis }\end{array}$ & $\begin{array}{l}\text { One table } \\
\text { spoonful of } \\
\text { honey is mixed } \\
\text { in cup of warm } \\
\text { water and oral } \\
\text { administered } \\
\text { for quick } \\
\text { recovery. }\end{array}$ & $48.1,51.3$ \\
\hline & & & & & Larva & $\begin{array}{l}\text { Nutrient } \\
\text { supplement }\end{array}$ & $\begin{array}{l}\text { Raw or cooked } \\
\text { larvae are } \\
\text { eaten }\end{array}$ & 41.2 \\
\hline & & & & & Honey & $\begin{array}{l}\text { Common } \\
\text { illness } \\
\text { cancer, } \\
\text { gastritis }\end{array}$ & 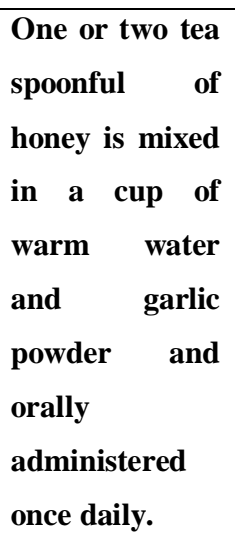 & $\begin{array}{l}81.4,35.8, \\
50.7\end{array}$ \\
\hline & & & & & Honey & Pneumonia & $\begin{array}{l}\text { Honey is mixed } \\
\text { with turmeric } \\
\text { powder and } \\
\text { externally } \\
\text { applied on } \\
\text { belly. }\end{array}$ & 10.8 \\
\hline \multirow[t]{2}{*}{35} & Apidae & $\begin{array}{l}\text { Apis lobpriosa } \\
\text { Smith } 1871\end{array}$ & Berega & Wild & Honey & $\begin{array}{l}\text { Appetizer } \\
\text { Common } \\
\text { illness, } \\
\text { cholera, cold } \\
\text { coughs, } \\
\text { vertigo, } \\
\text { diarrhoea }\end{array}$ & 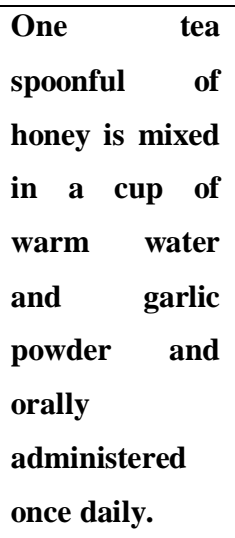 & $\begin{array}{l}45.7,56.1, \\
40.6, \\
87.1,38.5, \\
30.5\end{array}$ \\
\hline & & & & & $\begin{array}{l}\text { Bee } \\
\text { comb }\end{array}$ & $\begin{array}{l}\text { Appetizer } \\
\text { Common } \\
\text { illness, }\end{array}$ & $\begin{array}{l}\text { A small piece } \\
\text { of bee comb is } \\
\text { dissolved in a }\end{array}$ & $\begin{array}{ll}20.6, & 50.9, \\
90.5, & 85.4, \\
61.6 & \end{array}$ \\
\hline
\end{tabular}




\begin{tabular}{|c|c|c|c|c|c|c|c|c|}
\hline & & & & & & $\begin{array}{l}\text { coughs, } \\
\text { vertigo, } \\
\text { diarrhoea }\end{array}$ & $\begin{array}{l}\text { cup of warm } \\
\text { water and } \\
\text { orally } \\
\text { administered. }\end{array}$ & \\
\hline 36 & Apidae & $\begin{array}{l}\text { Lepidotrigona } \\
\text { arcifera } \\
\text { Cockerell, } \\
1929\end{array}$ & $\begin{array}{l}\text { Berega } \\
\text { gisim }\end{array}$ & wild & Honey & $\begin{array}{l}\text { Analgaesic, } \\
\text { blood } \\
\text { pressure, } \\
\text { cancer, chest } \\
\text { pain, } \\
\text { gastritis, } \\
\text { heart disease }\end{array}$ & $\begin{array}{l}\text { A small piece } \\
\text { of bee comb is } \\
\text { dissolved in a } \\
\text { cup of warm } \\
\text { water and } \\
\text { orally } \\
\text { administered. }\end{array}$ & $\begin{array}{l}12.4,42.1, \\
20.8,38.3, \\
50.1,28.8 .\end{array}$ \\
\hline 37 & & $\begin{array}{l}\text { Lophotrigona } \\
\text { canifrons } \\
\text { smith, } 1857\end{array}$ & $\begin{array}{l}\text { Madairaoni } \\
\text { daoma }\end{array}$ & Wild & $\begin{array}{l}\text { Nest } \\
\text { entranc } \\
\text { e }\end{array}$ & 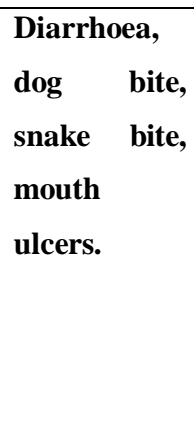 & $\begin{array}{l}\text { A small pieces } \\
\text { of } \\
\text { entrance is } \\
\text { dissolved in a } \\
\text { cup of warm } \\
\text { water and } \\
\text { orally } \\
\text { administered. }\end{array}$ & $\begin{array}{l}32.1,35,3 \\
30.8,47.8\end{array}$ \\
\hline 38 & Forcidae & $\begin{array}{l}\text { Oecophylla } \\
\text { smaragdina } \\
\text { Fabr.1775 }\end{array}$ & Garisma & A tree & $\begin{array}{l}\text { Whole } \\
\text { body }\end{array}$ & $\begin{array}{l}\text { Analgaesic, } \\
\text { fever, } \\
\text { headache. }\end{array}$ & $\begin{array}{l}\text { Cocked ants } \\
\text { with tulsi leaf } \\
\text { and } \\
\text { administered } \\
\text { orally for quick } \\
\text { recovery. }\end{array}$ & $\begin{array}{ll}50.1, & 35,6, \\
42,8 & \end{array}$ \\
\hline 39 & & & & & & $\begin{array}{l}\text { Malaria, } \\
\text { typhoid, } \\
\text { sinusitis }\end{array}$ & $\begin{array}{l}\text { Decoction of } \\
\text { boiled ants is } \\
\text { orally } \\
\text { administered } \\
\text { daily for two } \\
\text { week. }\end{array}$ & $\begin{array}{ll}13.9, & 18.3, \\
26.3 & \end{array}$ \\
\hline 40 & Vespidae & $\begin{array}{l}\text { Provespa } \\
\text { bathelemyi } \\
\text { (Byusson } \\
\text { 1905) }\end{array}$ & Berehor & Wild & Adult & $\begin{array}{l}\text { Analgaesic, } \\
\text { insomia, } \\
\text { oedema. }\end{array}$ & $\begin{array}{l}\text { Soup of boiled } \\
\text { wasps is orally } \\
\text { administered. }\end{array}$ & $\begin{array}{ll}12.3, & 26.1, \\
35.4 . & \end{array}$ \\
\hline 41 & & $\begin{array}{l}\text { Vespa } \\
\text { mandarinia } \\
\text { Smith, } 1852\end{array}$ & Bereshep & Wild & $\begin{array}{l}\text { Larva, } \\
\text { pupa }\end{array}$ & $\begin{array}{l}\text { Diabetes, } \\
\text { nutrient } \\
\text { supplement }\end{array}$ & $\begin{array}{l}\text { Raw larvae } \\
\text { and pupae are } \\
\text { eaten }\end{array}$ & $34.8,45.8$ \\
\hline
\end{tabular}




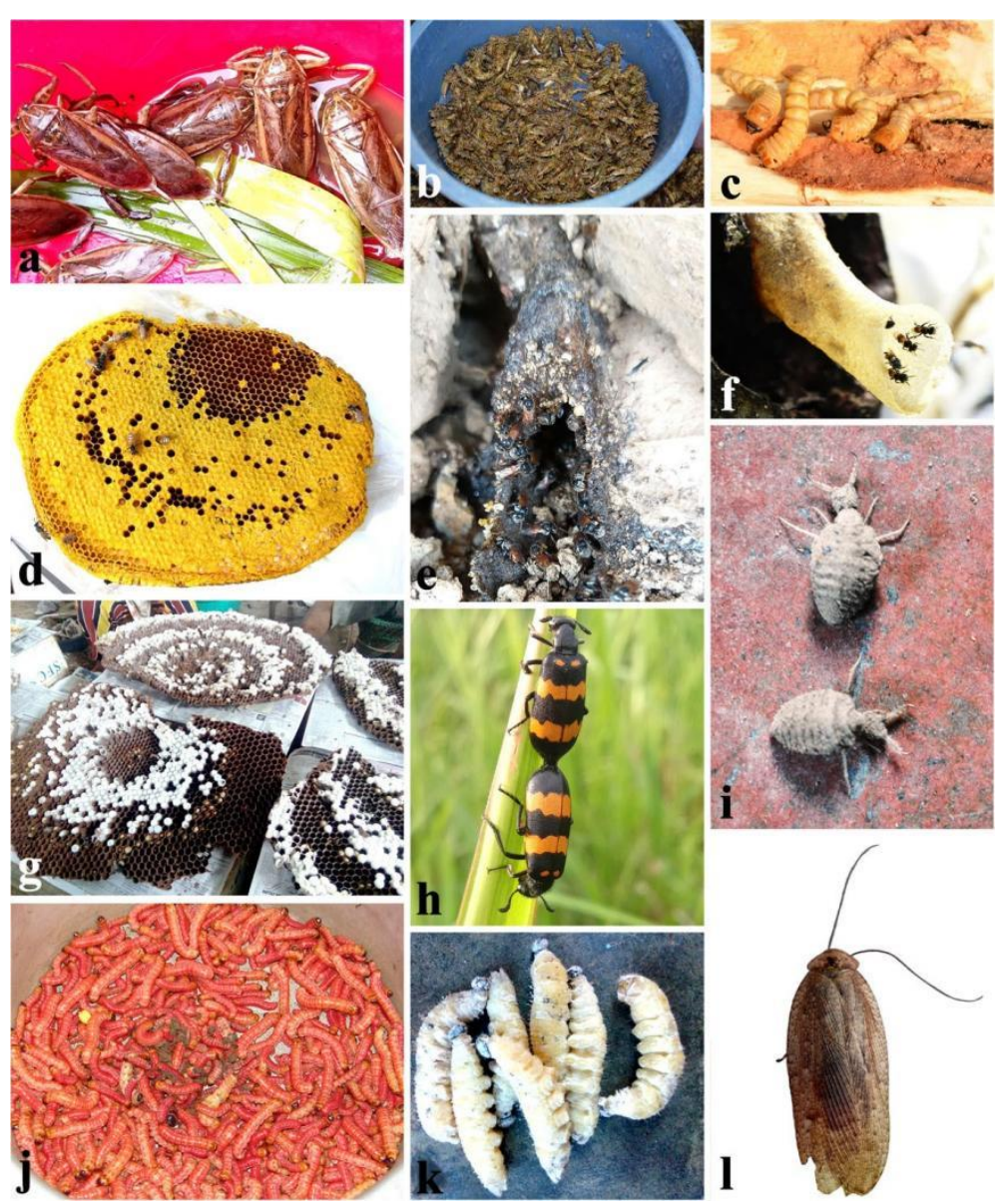

Fig. 4 Certain medicinal insect and insect products of Semkhor. a Giant water bug Lethocerus indicus, b dragonfly nymphs, c large timber-boring larvae, $d$ freshly harvested Apis florea bee comb, e, f nest entrances of stingless bees, $g$ Vespa mandarinia comb sold at local market, Maibang district, h blister beetle Mylabris sp., i larvae of antlion Myrmeleon sp., j larvae of Cossus sp., k larvae of banana skipper Erionata torus, I Epilambra sp. cockroach 
Table 2 Important insect species for gastrointestinal and respiratory problems

\begin{tabular}{|c|c|c|}
\hline Endocrine Issues (FL \%) & Respiratory Issues (FL \%) & Gastrointestinal (FL \%) \\
\hline Melanoplus sp. (51.0) & Apis laboriosa (82.7) & Mylabris sp. (100.0) \\
\hline Gryllus spp. (50.1) & Apis florea(82.7) & Myrmeleon spp. (57.1) \\
\hline Cybister limbatus (46.9) & Udonga montana (68.8) & Lepidotrigona arcifera (47.8) \\
\hline Cybister tripunctatus lateralis (46.9) & Lethocerus indicus (47.5) & Lophotrigona canifrons (47.8) \\
\hline Notobitus meleagris (46.3) & Crocothemis servilia servilia (46.8) & Laccotrephes ruber (35.7) \\
\hline Tarbinskiellus portentosus (41.5) & Diplacodes trivialis (46.8) & Udonga montana (35.7) \\
\hline Apis dorsata dorsata (37.1) & Neurothemis fulvia (46.8) & Apis cerana indica (31.6) \\
\hline Apis laboriosa (34.5) & Orthetrum pruinosum neglectum (46.8) & Lethocerus indicus (26.7) \\
\hline Apis florea (34.5) & Orthetrum sabina sabina (46.8) & Hydrophilus caschmirensis (20.1) \\
\hline Laccotrephes ruber (32.1) & Orthetrum triangulare (46.8) & Crocothemis servilia servilia (18.7) \\
\hline Lepidotrigona arcifera (29.5) & Pantala flavescens (46.8) & Diplacodes trivialis(18.7) \\
\hline Lophotrigona canifrons (29.5) & Potamarcha congener (46.8) & Neurothemis fulvia (18.7) \\
\hline Apis cerana indica (20.3) & Apis dorsata dorsata (43.3) & Orthetrum pruinosum neglectum (18.7) \\
\hline Epilampra sp. (20) & Apis cerana indica (35.4) & Orthetrum sabina sabina (18.7) \\
\hline Lethocerus indicus (19.8) & Oecophylla smaragdina (32.7) & Orthetrum triangulare triangulare (18.7) \\
\hline Batocera rubus (9.7) & Lepidotrigona arcifera (20.3) & Pantala flavescents (18.7) \\
\hline Batocera parryi (9.7) & Lophotrigon acanifrons (20.3) & Potamarcha congener (18.7) \\
\hline Batocera rufomaculata (9.7) & Cossus sp. (4.8) & Carausius sp. (15.2) \\
\hline Cossus sp. (7.7) & Orthosoma brunneum (3.5) & \\
\hline Orthosoma brunneum (5.9) & & \\
\hline
\end{tabular}


Table 3 Informant consensus factor of every human health conditions

\begin{tabular}{|c|c|c|c|c|c|c|c|c|c|c|c|c|c|c|c|c|c|c|c|c|c|c|}
\hline \multirow{2}{*}{\begin{tabular}{|l} 
Category of indigenous \\
uses \\
\end{tabular}} & \multicolumn{7}{|c|}{ No. of species (Ns) } & \multicolumn{8}{|c|}{ No. of use reports (Nur) } & \multicolumn{7}{|c|}{ ICF } \\
\hline & $\mathbf{A N}$ & A & C & KH & & $\mathbf{L}$ & S & AN & $\mathbf{A}$ & & C & KH & $\mathbf{K}$ & $\mathbf{L}$ & $\mathbf{S}$ & AN & $\mathbf{A}$ & $\mathbf{C}$ & KH & $\mathbf{K}$ & $\mathbf{L}$ & $S$ \\
\hline Gastrointestinal problems & 10 & $\beta$ & 8 & 5 & 7 & 8 & 6 & 162 & 22 & & 60 & 28 & 52 & 141 & 142 & 0.94 & 0.90 & 0.88 & 0.85 & 0.88 & 0.95 & 0.96 \\
\hline Dermatological problems & 7 & 4 & 14 & 3 & $\beta$ & 4 & 6 & 125 & 64 & & 83 & 43 & 33 & 80 & 128 & 0.95 & 0.95 & 0.84 & 0.95 & 0.93 & 0.96 & 0.96 \\
\hline Respiratory problems & 10 & 2 & 10 & - & $\beta$ & 5 & 4 & 64 & 24 & & 12 & 6 & 80 & 162 & 65 & 0.85 & 0.95 & 0.92 & - & 0.97 & 0.97 & 0.95 \\
\hline $\begin{array}{l}\text { Gynaecologic } \\
\text { /Andrologic }\end{array}$ & 2 & 5 & 3 & - & - & 1 & 4 & 40 & - & & 27 & - & - & 7 & 10 & 0.97 & - & 0.92 & - & - & 1.00 & 0.66 \\
\hline Pain & 7 & 5 & 2 & - & 1 & 6 & 8 & 85 & 16 & & 51 & - & 8 & 40 & 131 & 0.92 & 0.73 & 0.98 & - & 1.00 & 0.87 & 0.94 \\
\hline Fever (including malaria) & 1 & - & 8 & - & - & 3 & 2 & 8 & - & & 51 & 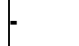 & - & 43 & 27 & 1.00 & - & 0.86 & - & - & 0.95 & 0.96 \\
\hline Skeleto-muscular problems & 10 & - & 6 & 2 & - & 8 & 2 & 79 & - & & 65 & 11 & - & 74 & 42 & 0.88 & - & 0.92 & 0.90 & - & 0.90 & 0.97 \\
\hline Ophthalmological & 10 & - & - & - & - & 2 & - & 60 & - & & & - & 5 & 33 & - & 0.84 & - & - & - & - & 0.96 & - \\
\hline Urological & 1 & - & - & - & - & - & - & 8 & - & & - & - & 5 & - & - & 1.00 & - & - & - & - & - & - \\
\hline Poisonous animal bites & $\beta$ & 2 & 1 & - & - & - & - & 48 & 17 & & 18 & - & - & - & - & 0.95 & 0.93 & 1.00 & - & - & - & - \\
\hline Cardiovascular & 4 & - & 3 & - & - & 3 & 3 & 35 & - & & 35 & - & 5 & 48 & 31 & 0.91 & - & 0.94 & - & - & 0.95 & 0.93 \\
\hline Diabetes & 1 & - & 1 & - & - & 2 & 2 & 11 & - & & 10 & - & 5 & 41 & 17 & 1.00 & - & 1.00 & - & - & 0.97 & 0.93 \\
\hline Oncologic & 1 & 5 & - & - & F & 2 & - & 4 & - & & & - & - & 12 & - & 1.00 & - & - & - & - & 0.90 & - \\
\hline Cultural filiations & - & 2 & - & - & - & - & - & $F$ & 10 & & 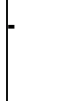 & - & - & - & - & - & $\begin{array}{l}0.8 \\
8\end{array}$ & - & - & - & - & - \\
\hline Others & 8 & 8 & 10 & 5 & 6 & 10 & 10 & 181 & & 172 & 141 & 102 & 152 & 321 & 380 & 0.96 & 0.95 & 0.93 & 0.96 & 0.96 & 0.97 & 0.97 \\
\hline
\end{tabular}



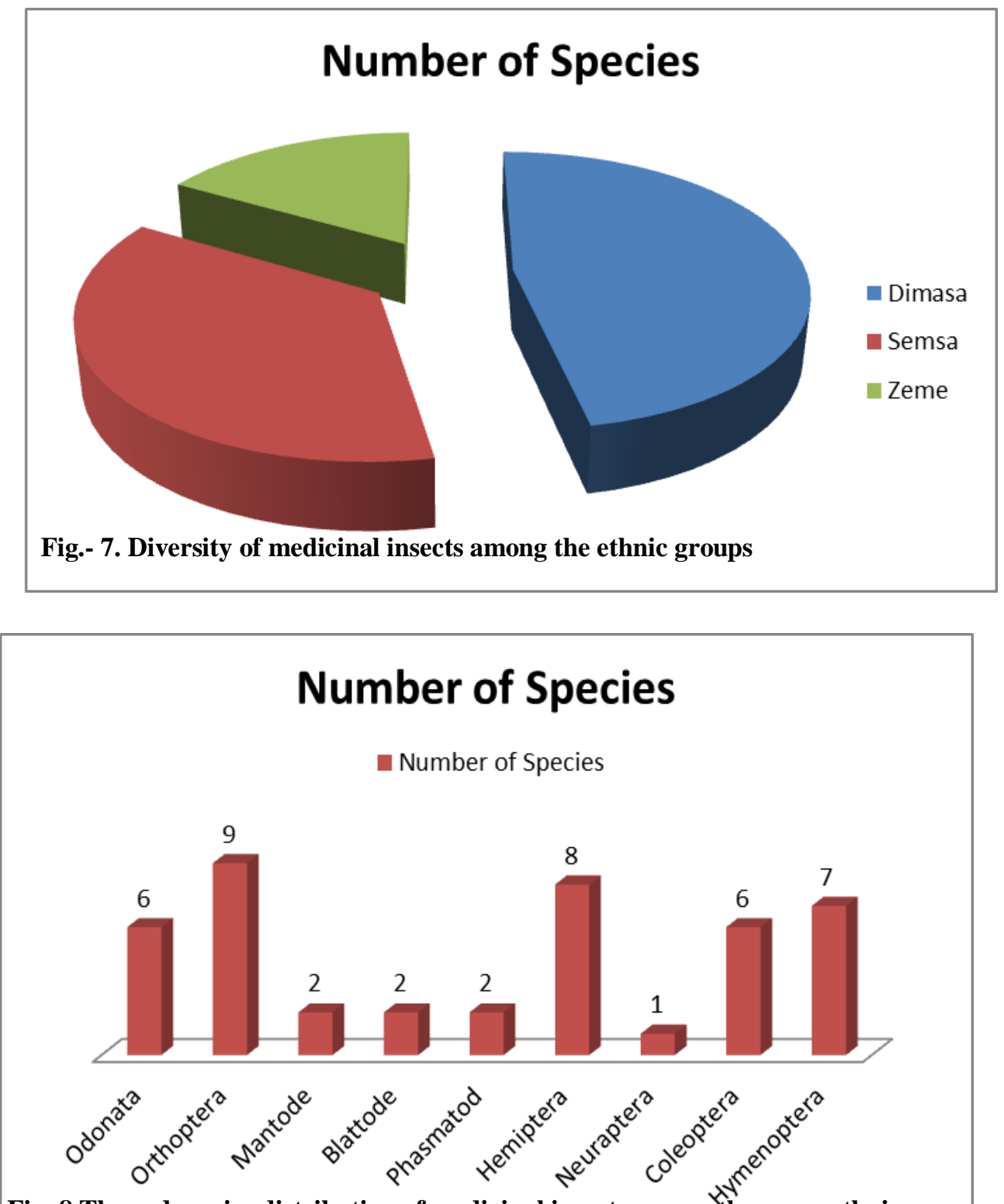

Fig. 8 The order-wise distribution of medicinal insects among the seven ethnic groups

References

1. Kakati LN, Doulo V. Indigenous knowledge system of zootherapeutic use by Chakhesang tribe of Nagaland, India. J Hum Ecol. 2002;13(6):419-23.

2. Jamir NS, Lal P. Ethnozoological practices among Naga tribes. Indian J Tradit Knowl. 2005;4(1):100-4.

3. Kakati LN, Ao B, Doulo V. Indigenous knowledge of zootherapeutic use of vertebrate origin by the Ao Tribe of Nagaland. J Hum Ecol. 2006;19(3):163-7.

4. Mozhui L, Kakati LN, Ao B. Entomophagy and entomotherapy of Lotha tribe in Nagaland. Nagaland 
Univ Res J. 2017;10:138-51.

5. Pongener A, Ao B, Yenisetti SC, Lal P. Ethnozoology and entomophagy of Ao tribe in the district of Mokokchung, Nagaland. Indian J Tradit Knowl. 2019;18(3):508-15.

6. Mozhui L, Kakati LN, Kiewhuo P, Changkija S. Traditional knowledge of the utilization of edible insects in Nagaland, North-East India. Foods. 2020;9:852. https://doi.org/10.3390/foods9070852.

7. Ao A, Singh HK. Utilisation of insectsas human food in Nagaland. Ind J Entomol. 2004;66:308-20.

8. Singson L, Das AN, Ahmed R. Edible insects of Nagalandandits nutritionalbenefit. Periodic Res. 2016;5:1-7.

9. Meyer-Rochw VB, Changkija S. Uses of insects as human food in Papua New Guinea, Australia, and North-East India: cross-cultural considerations and cautious conclusions. Ecol Food Nutr. 1997;36(24):159-85.

10. Alves RRN, Barboza RRD. The role of animals in human culture. In: RRN A, Albuquerque UP, editors. Ethnozoology Animals in our lives. London: Academic Press; 2018. p. 277-301.

11. Alves RRN, Rosa IL. Why study the use of animal products in traditional medicine. $\mathbf{J}$ EthnobiolEthnomed. 2005;1:5.

12. Costa-Neto EM. Entomotherapy, or the medicinal use of insects. J Ethnobiol. 2005;25:93-114.

13. Shelomi M. Why we still don't eat insects: assessing entomophagy promotion through a diffusion of

14. innovations framework. Trends Food Sci Technol. 2015;45:311-8.

15. Meyer-Rochow VB. Therapeutic arthropods and other, largely terrestrial, folk- medicinally important invertebrates: a comparative study and review. J EthnobiolEthnomed. 2017;13:9.

16. Feng Y, Zhao M, He Z, Chen Z, Sun L. Research and utilization of medicinal insects in China. Entomol Res. 2009;39:313-6.

17. Seabrooks L, Hu L. Insects: an underrepresented resource for the discovery of biologically active natural products. Acta Pharm Sin. 2017;B7(4):409-26.

18. Cherniack EP. Bugs as drugs part 1: Insects. The new alternative medicine for the 21 st century? Altern Med Rev. 2010;15(2):124-35.

19. Czaja O. The use of insects in Tibetan medicine. Etudes Mongoles et Sibériennes, Centrasiatiques et Tibétaines. 2019;50:1-56.

20. Umemura J. Konchu honzo. Nagoya: Shobunkan (Reprinted 1988 by Tokyo Kagaku Shoin Co. Ltd.); 1943.

21. Pemberton RW. Insects and other arthropods used as drugs in Korea. J Ethnopharmacol. 1999;65:20716. https://doi.org/10.1016/s0378-8741(98)00209-8.

22. Okamoto H, Muramatsu S: Shokuyou oyobi yakuyo konchu ni kansurus chousa [Research report of edible and medicinal insects in Korea]. Kangyo Mohanjo Kenkyo Hokoku No 7, Suwon. 1922, 1-151.

23. Meyer-Rochow VB. Ethno-entomological observations from North Korea (officially known as the “Democratic People's Republic of Korea”). J Ethnobiol Ethnomed. 2013. https://doi.org/10.1186/1746- 
4269-9-7.

24. Senthilkumar N, Barthakur ND, Rao L. Bioprospecting with reference to medicinal insects and tribes in India: an overview. Ind Forester. 2008;12: 1575-91.

25. Sharma S. Edible and therapeutic uses of insects among the various tribes of Dimoria Development Block of Assam, India. Scenario Environ Res Dev. 2018:101-8 ISBN: 978-93-5346-498-1.

26. Shrivastava SK, Prakash A. Entomotherapy- an unexplored frontier for make in India: a review. J Applied Zool Res. 2015;26(2):113-23.

27. Ayekpam N, Singh NI, Singh TK. Edible and medicinal insects of Manipur. Ind J Entomol. 2014;76(3):256-9.

28. Srivastava SK, Babu N, Pandey H. Traditional insect bioprospecting - as human food and medicine. Indian J Tradit Knowl. 2009;8(4):485-94.

29. Percino-Daniel N, Buckley D, Garcia-Paris M. Pharmacological properties of blister beetles (Coleoptera; Meloidae) promoted their integration into the cultural heritage of native rural Spain as inferred by vernacular names diversity, traditions, and mitochondrial DNA. J Ethnopharmacol. 2013;147:570-83.

30. Vallejo R, González JA. The use of the headlouse as a remedy for jaundice in Spanish folk medicine: an overview. J Ethnobiol Ethnomed. 2013;9(1):52. https://doi.org/10.1186/1746-4269-9-52.

31. Zengin E, Karaca I. Böceklerin ilaçola rakkullanılmas. Adü Ziraat Derg. 2017; 14(1):71-8.

32. Kutalek R, Prinz A. Ethnoentomologie Afrikas - Insekten in traditioneller Therapie und Prophylaxe. Denisia. 2004;13:529-39.

33. Jideani AIO, Netshiheni RK. Selected edible insects and their products in traditional medicine, food, and pharmaceutical industries in Africa: utilization and prospects. In: Mikkola H, editor. Future Foods: Chapter 3. London: InTech Publ; 2017. p. 55-69.

34. Costa-Neto E, Ramos-Elorduy J, Pino JM. Los Insectos medicinales de Brasil: primeros resultado. Bol Soc Entomol Aragonesa. 2006;38:395-414.

35. Mozhui L, Kakati LN, Changkija SA. Study on the use of insects as food in seven tribal communities in Nagaland, Northeast India. J Hum Ecol. 2017; 60(1):42-53. https://doi.org/10.1080/09709274.2017.1399632.

36. Myers N, Muttermeier RA, Muttermeier CA, da Fonseca GAB. Kent J. Biodiversity hot spots for conservation priorities. Nature. 2000;403:853-8.

37. Changkija S. Biodiversity of Nagaland. Kohima: Department Forest Ecology, Environment and Wildlife; 2014.

38. Anonymous. Census of India. Nagaland, Data Highlights: The Scheduled Tribes. 2001 http://censusindia.gov.in (Retrieved on 20 May, 2020) 
39. Friedman J, Yaniv Z, Dafni A, Palewitch D. A preliminary classification of the healing potential of medicinal plants, based on a rational analysis of an ethnopharmacological field survey among Bedouins in the Negev Desert, Israel. J Ethnopharmacol. 1986;16:275-87. https://doi.org/10.1016/0378-8741 (86)90094-2.

40. Andrade-Cetto A. Ethnobotanical study of the medicinal plants from Tlanchinol, Hidalgo, México. J Ethnopharmacol. 2009;122(1):163-71. https:// doi.org/10.1016/j.jep.2008.12.008.

41. Heinrich M, Ankli A, Frei B, Weimann C, Sticher O. Medicinal plants in Mexico: Healers' consensus and cultural importance. Soc Sci Med. 1998;47: 1859-71. https://doi.org/10.1016/S0277-9536(98)001816.

42. Mandal MD, Mandal S. Honey: Its medicinal property and antibacterial activity. Asian Pac J Trop Biomed. 2011;1(2):154-60. https://doi.org/10.1016/ S2221-1691(11)60016-6.

43. Rao PV, Krishnan KT, Salleh N, Gan SH. Biological and therapeutic effects of honey produced by honey bees and stingless bees: A comparative review. Braz Pharmacogn. 2016;26:657-64. https://doi.org/10.1016/j.bjp.2016.01.012.

44. Meo SA, Al-Asiri SA, Mahesar AL, Ansari MJ. Role of honey in modern medicine. Saudi J Biol Sci. 2017;24:975-8. https://doi.org/10.1016/j.sjbs.2016.12.010.

45. Aurongzeb M, Azim K. Antimicrobial properties of natural honey: a review of literature. Pak J Biochem Mol Biol. 2011;44(3):118-24.

46. Namias N. Honey in the management of infections. Surg Infect. 2003;4(2): 219-26. https://doi.org/10.1089/109629603766957022.

47. Souza B, Roubik D, Barth O, Heard T, Enriquez E, Carvalho C, Villas-Boas J, Marchini L, Locatelli J, Persano-Oddo L. Composition of stingless bee honey: setting quality standards. Interciencia (Caracas). 2006;31:865-7.

48. Othman N. Does honey have the characteristics of natural cancer vaccine? J Tradit Complement Med. 2012. https://doi.org/10.1016/S2225-4110(16)3 0113-4.

49. Meda A, Lamien CE, Millogo J, Romito M, Nacoulma OG. Therapeutic uses of honey and honeybee larvae in central Burkina Faso. J Ethnopharmacol. 2004;95(1):103-7. https://doi.org/10.1016/j.jep.2004.06.016.

50. Mahawar MM, Jaroli DP. Animals and their products utilized as medicine by the inhabitants surrounding the Ranthambhore national park, India. J Ethnobiol Ethnomed. 2006;2:46.

51. Mahawar MM, Jaroli DP. Traditional knowledge on zootherapeutic uses by the Saharia tribe of Rajasthan, India. J Ethnobiol Ethnomed. 2007;3:25.

52. Wilsanand V, Varghese P, Rajitha P. Therapeutics of insects and insect products in South Indian traditional medicine. Indian J Tradit Knowl. 2007;6: 563-8.

53. Solavan A, Paulmurugan R, Wilsanand V, Sing A. Traditional therapeutic uses of animals among tribal population of Tamil Nadu. Indian J Tradit Knowl. 2004;3(2):198-205. 
